\title{
Correction: Luteolin selectively kills STAT3 highly activated gastric cancer cells through enhancing the binding of STAT3 to SHP-1
}

Shiyu Song ${ }^{1}$, Zhonglan Su${ }^{2}$, Hui Xu' ${ }^{1}$, Mengyuan Niu' ${ }^{1}$ Xiufang Chen ${ }^{3}$, Haiyan Min ${ }^{1}$, Bin Zhang ${ }^{4}$, Guibo Sun ${ }^{5}$, Sijing Xie ${ }^{1}$, Hongwei Wang ${ }^{1}$ and Qian Gao ${ }^{1}$

Correction to: Cell Death \& Dieases.; https://doi.org/ 10.1038/cddis.2017.38; published online 9 February 2017.
The PDF and HTML versions of the article have been updated to include the Creative Commons Attribution 4.0 International License information.

Published online: 16 July 2018

Correspondence: Hongwei Wang (hwang@nju.edu.cn) or

Qian Gao (qian_gao@nju.edu.cn)

${ }^{1}$ Center for Translational Medicine and Jiangsu Key Laboratory of Molecular

Medicine, Medical School of Nanjing University, Nanjing, China

${ }^{2}$ Department of Dermatology, The First Affiliated Hospital of Nanjing Medical

University, Nanjing, China

${ }^{3}$ Department of Biochemistry, School of Basic Medical Sciences, Wenzhou

Medical University, Wenzhou, China

${ }^{4}$ Central Laboratory, Nanjing Chest Hospital, Medical School of Southeast

University, Nanjing, China

${ }^{5}$ Institute of Medicinal Plant Development, Chinese Academy of Medical

Sciences and Peking Union Medical College, Beijing, China

\section{(-) The Author(s) 2018}

(c) (i) Open Access This article is licensed under a Creative Commons Attribution 4.0 International License, which permits use, sharing, adaptation, distribution and reproduction in any medium or format, as long as you give appropriate credit to the original author(s) and the source, provide a link to the Creative Commons license, and indicate if changes were made. The images or other third party material in this article are included in the article's Creative Commons license, unless indicated otherwise in a credit line to the material. If material is not included in the article's Creative Commons license and your intended use is not permitted by statutory regulation or exceeds the permitted use, you will need to obtain permission directly from the copyright holder. To view a copy of this license, visit http://creativecommons.org/licenses/by/4.0/. 